Article

\title{
Equilibrium, Kinetic and Thermodynamic Studies for Sorption of Phosphate from Aqueous Solutions Using ZnO Nanoparticles
}

\author{
Tra Huong Do ${ }^{1, *}$, Van Tu Nguyen ${ }^{2}$, Quoc Dung Nguyen ${ }^{1}{ }^{\mathbb{D}}$, Manh Nhuong Chu ${ }^{1}$, \\ Thi Cam Quyen $\mathrm{Ngo}^{3,4}$ and Lam Van Tan ${ }^{3,4, *}$ \\ 1 Thai Nguyen University of Education, Thai Nguyen University, 20 Luong Ngoc Quyen, \\ Thai Nguyen City 250000, Vietnam; dungnq@tnue.edu.vn (Q.D.N.); \\ chumanhnhuong@dhsptn.edu.vn (M.N.C.) \\ 2 Institute of Chemistry and Materials, Institute of Military Science and Technology, 17 Hoang Sam, Cau Giay, \\ Hanoi 100000, Vietnam; nguyenvantu882008@yahoo.com \\ 3 NTT Hi-Tech Institute, Nguyen Tat Thanh University, Ho Chi Minh City 700000, Vietnam; \\ ntcquyen@ntt.edu.vn \\ 4 Center of Excellence for Green Energy and Environmental Nanomaterials, Nguyen Tat Thanh University, \\ Ho Chi Minh City 700000, Vietnam \\ * Correspondence: huongdt.chem@tnue.edu.vn (T.H.D.); lvtan@ntt.edu.vn (L.V.T.)
}

Received: 28 September 2020; Accepted: 27 October 2020; Published: 2 November 2020

\begin{abstract}
In this study, $\mathrm{ZnO}$ nanoparticles were fabricated by using the hydrothermal method for adsorption of phosphate from wastewater. The obtained $\mathrm{ZnO}$ nanorods were characterized by powder X-ray diffraction spectroscopy (XRD), scanning electron microscopy (SEM), specific surface area (BET) and energy dispersive $\mathrm{X}$-ray spectroscopy (EDS). The $\mathrm{ZnO}$ materials were applied for adsorption of phosphate from water using batch experiments. The effects of $\mathrm{pH}$ (4-10), adsorption time (30-240 $\mathrm{min}$ ), the amount of adsorbent $(0.1-0.7 \mathrm{~g} / \mathrm{L})$ and initial concentration of phosphate $(147.637-466.209 \mathrm{mg} / \mathrm{L})$ on the adsorption efficiency were investigated. The optimum condition was found at $\mathrm{pH}=5$ and at an adsorption time of $150 \mathrm{~min}$. The adsorption was fitted well with the Langmuir isotherm and the maximum adsorption capacity was calculated to be $769.23 \mathrm{mg} / \mathrm{g}$. These results show that $\mathrm{ZnO}$ nanomaterial would highly promising for adsorbing phosphate from water. The adsorption of phosphate on $\mathrm{ZnO}$ nanomaterials follows the isothermal adsorption model of Langmuir, Tempkin and Freundlich with single-layer adsorption. There is weak interaction between the adsorbent and the adsorbate. Phosphate adsorption of the $\mathrm{ZnO}$ nanomaterials follows Lagergren's apparent second-order kinetic model and was spontaneous and exothermic.
\end{abstract}

Keywords: nanoparticles; $\mathrm{ZnO}$; equilibrium; kinetic; thermodynamic; phosphate; aqueous solution

\section{Introduction}

The wide direct bandgap and large exciton binding energy of zinc oxide $(\mathrm{ZnO})$ have conferred the material unique electrical and photovoltaic properties and enabled its applications in the fields of fluorescence [1], photocatalytic catalysis [2], electric fire, gas sensors [3,4], electrochemical sensors [5] and solar cells [6]. ZnO can be synthesized by using various methods, including sputtering [7], sol-gel [8], co-precipitation [9], gel burning [10] and hydrothermal [11]. Depending on the synthesis routine, the morphologies of $\mathrm{ZnO}$ could be varied, ranging from nanorods [2], nanospheres [4], nanopores [1], nanoparticles [9] and many kinds of structures of nanorods, such as nanobelts, nanocombs and nanoforests [5]. In most synthesis routines, $\mathrm{ZnO}$ plays the role as an $n$-type semiconductor with electrical amphoteric properties [12]. In addition, selection of an appropriate synthesis method is also 
important in ensuring operational ease and in avoiding the technical difficulties of the fabricating process. At the nano scale, $\mathrm{ZnO}$ finds a wide range of applications in environmental remediation, bactericidal agents and in electronic devices, of which the use as adsorbent materials for removal of cation and anion pollutants features prominently due to its largely improved surface area compared to its bulk counterparts [13].

Treatment of phosphate represents an important aspect of wastewater treatment. Excessive phosphate causes overgrowth of photosynthetic cyanobacteria and algae and in turn accelerated eutrophication in water ecosystems [14]. Phosphorus could enter water bodies through effluents from households, industrial or agricultural activities, and exists in the form of $\mathrm{H}_{2} \mathrm{PO}_{4}{ }^{-}, \mathrm{HPO}_{4}{ }^{-2}$ and $\mathrm{PO}_{4}{ }^{-3}$ organic phosphate and polyphosphate [14-17]. In water, hydrolysis could occur, transforming polyphosphates and organic phosphate into other phosphate forms [18]. Therefore, industrial and agricultural discharge management, especially in terms of treatment of ammonium and phosphate, is pivotal in ensuring environmental stability and preventing water-derived health risks $[19,20]$. Because treatment of environmental pollution requires a large amount of adsorbents, scalability of a treatment method largely depends on its ability to easily fabricate bulk materials with a high adsorption efficiency. The hydrothermal method has been shown to be an appropriate method to synthesize $\mathrm{ZnO}$ due to a number of advantages, including inexpensive chemicals and ease of mass production. However, the maximum adsorption efficiency of fabricated $\mathrm{ZnO}$ requires optimization of all factors of adsorption, such as $\mathrm{pH}$, time, the volume of the adsorbent, the initial concentration as well as careful investigation of the adsorption isothermal model, adsorption kinetic and adsorption thermal dynamic, which are relatively scarce in the literature [14-17].

In this report, we present the results of studies on isothermal adsorption, kinetics, thermodynamics of phosphate adsorption $\left(\mathrm{PO}_{4}^{3-}\right)$ removal in aqueous environments by using $\mathrm{ZnO}$ nanomaterials fabricated by the hydrothermal method.

\section{Materials and Methods}

\subsection{Preparation of Materials}

Zinc oxide nanomaterials were prepared by the hydrothermal method from a mixture of $25 \mathrm{~mL}$ $\mathrm{Zn}\left(\mathrm{NO}_{3}\right)_{2} 0.1 \mathrm{M}+\mathrm{NaOH} 0.1 \mathrm{M}+20 \mathrm{~mL} \mathrm{C}_{2} \mathrm{H}_{5} \mathrm{OH}$ (ratio $\mathrm{C}_{2} \mathrm{H}_{5} \mathrm{OH}: \mathrm{H} 2 \mathrm{O}=1: 1$ ), $\mathrm{pH}=11$. Briefly, $0.6525 \mathrm{~g}$ of $\mathrm{Zn}\left(\mathrm{NO}_{3}\right)_{2} .4 \mathrm{H}_{2} \mathrm{O}$ was weighed accurately and diluted to $25 \mathrm{~mL}$ of $\mathrm{Zn}\left(\mathrm{NO}_{3}\right)_{2} 0.1 \mathrm{M}$ to produce Solution A. An amount of $0.1 \mathrm{~g}$ of $\mathrm{NaOH}$ was dissolved with water in a $25 \mathrm{~mL}$ volumetric flask, forming a $\mathrm{NaOH}$ solution with a $0.1 \mathrm{M}$ concentration (Solution B). Solution A was added to Solution B. Afterwards, $20 \mathrm{~mL}$ of $\mathrm{C}_{2} \mathrm{H}_{5} \mathrm{OH}$ (ratio $\mathrm{C}_{2} \mathrm{H}_{5} \mathrm{OH}: \mathrm{H}_{2} \mathrm{O}=1$ : 1) was added to the reaction mixture above. The $\mathrm{pH}$ of the solution was maintained at 11 . The reaction mixture was stirred on the stirrer for $20 \mathrm{~min}$, and then the whole reaction mixture was heated in an autoclave at $180{ }^{\circ} \mathrm{C}$ for $24 \mathrm{~h}$. The samples were taken for centrifugation, followed by washing to a $\mathrm{pH}=7$ to obtain a white, viscous gel. After obtaining the $\mathrm{ZnO}$ nanoparticles, the samples were heated in an air atmosphere at $350{ }^{\circ} \mathrm{C}$ for $10 \mathrm{~h}$ to remove the organic impurities.

\subsection{Characterization}

The crystalline structure and morphology of the sample were examined by using a powder X-ray diffraction spectrometer (XRD, X'Pert Pro Panalytical, Almelo, The Netherlands) equipped with $\mathrm{Cu}-\mathrm{K}_{\alpha}$ radiation $(\lambda=1.5418 \AA$ ) and an emission scanning electron microscope (SEM, S4800, JEOL, Tokyo, Japan), respectively. To determine the specific surface area, the Brunauer, Emmett and Teller (BET) method was used, using Tri Start 3000 equipment, Micromeritics. The distribution size of the sample was determined by the laser scattering method on HORIBA Laser Scattering Particle Size Distribution. The concentration of $\mathrm{PO}_{4}^{3-}$ before and after adsorption were determined by the UV-Vis method (Hitachi UH5300) at the University of Medicine and Pharmacy, Thai Nguyen University. 


\subsection{Assessment of the Prepared $\mathrm{ZnO}$ Nanopowder for Phosphorus Decontamination}

A series of batch experiments was carried out to assess the adsorptivity of the as-synthesized $\mathrm{ZnO}$ nanoparticles against phosphorus. The stock solution containing potassium phosphate at a concentration of $1000 \mathrm{mg} \mathrm{PO}_{4}$ per liter was first prepared to simulate wastewater. The synthesized $\mathrm{ZnO}$ nanoparticle was introduced into $25 \mathrm{~mL}$ of the diluted synthetic waste solution at a predetermined ratio and phosphorus concentration, and then mixed for a certain time period. The reaction took place in $50 \mathrm{~mL}$ polypropylene plastic vials under end-over-end shaking at $40 \mathrm{rpm}$. Samples were taken after specific intervals from the tube for the measurement of phosphorus concentrations using the ascorbic acid-molybdate blue method [21]. The method is based on the principle that ascorbic acid could reduce phosphomolybdic acid, which is formed by the orthophosphate and molybdate interaction, to form a complex with a blue color that is measurable by using a spectrophotometer at $885 \mathrm{~nm}$. Adsorbed phosphorus would be quantified based on the initial $\left(C_{0}\right)$ and final measured concentration $(C)$. The contact time, initial phosphorus concentration, material dosage and solution $\mathrm{pH}$ were varied to find out its effect on the adsorption capacity of the prepared nano- $\mathrm{ZnO}$.

\subsection{Adsorption Capacity of the $\mathrm{PO}_{4}^{3-}$}

The adsorption experiments were investigated under a varying $\mathrm{pH}$, time, weight of $\mathrm{ZnO}$ and initial $\left(\mathrm{PO}_{4}^{3-}\right)$ concentration. The fixed conditions included the room temperature and a shaking rate of 200 revolutions per minute (rpm).

The effect of the initial $\mathrm{pH}$ was measured by adding $0.025 \mathrm{~g}$ of $\mathrm{ZnO}$ to $50.0 \mathrm{~mL}$ of the $\mathrm{PO}_{4}^{3-}$ concentration of $150 \mathrm{mg} / \mathrm{L}$, with the different $\mathrm{pH}$ values ranging from 1 to 10 , followed by shaking for $150 \mathrm{~min}$. The $\mathrm{pH}$ solution was adjusted with either by $\mathrm{NaOH}$ or $\mathrm{HNO}_{3}$ solutions $(0.1 \mathrm{M})$. The effect of the adsorption time was examined by adding $0.025 \mathrm{~g} \mathrm{ZnO}$ to $50.0 \mathrm{~mL} \mathrm{PO}_{4}^{3-}$ solution with an initial concentration of $150 \mathrm{mg} / \mathrm{L}$, for a period that ranged from 30 to $240 \mathrm{~min}$, at $\mathrm{pH}=5$. The effect of the $\mathrm{ZnO}$ mass was achieved by gradually increasing the mass of $\mathrm{ZnO}$ from 0.005 to $0.035 \mathrm{~g}$ into a $50.0 \mathrm{~mL}$ $\mathrm{PO}_{4}^{3-}$ solution with the initial concentration of $162.1978 \mathrm{mg} / \mathrm{L}$, in $120 \mathrm{~min}$, at $\mathrm{pH}=5$. The effect of the initial concentration of $\mathrm{PO}_{4}^{3-}$ was examined by adding $0.025 \mathrm{~g} \mathrm{ZnO}$ to $50.0 \mathrm{~mL} \mathrm{PO}_{4}^{3-}$ solution with a concentration varying from 150 to $450 \mathrm{mg} / \mathrm{L}$, in $150 \mathrm{~min}$, at $\mathrm{pH}=5$. After the above processes, the samples were centrifuged at a rate of $4000 \mathrm{rpm}$ for $10 \mathrm{~min}$. The concentration of $\mathrm{PO}_{4}^{3-}$ before and after adsorption were determined by the UV-Vis method (Hitachi UH5300) at the University of Medicine and Pharmacy, Thai Nguyen University.

The adsorption capacity and adsorption efficiency were calculated according to the formula

$$
\begin{gathered}
q=\frac{\left(\mathrm{C}_{0}-\mathrm{C}_{\mathrm{cb}}\right) \mathrm{V}}{\mathrm{M}} \\
\mathrm{H} \%=\frac{\left(\mathrm{C}_{0}-\mathrm{C}_{\mathrm{cb}}\right)}{\mathrm{C}_{0}} \times 100 \%
\end{gathered}
$$

where $\mathrm{V}$ is the volume of the solution $(\mathrm{L}), \mathrm{M}$ is the mass of the adsorbent $(\mathrm{g}), \mathrm{C}_{0}$ is the initial solution concentration $(\mathrm{mg} / \mathrm{L}), \mathrm{Ccb}$ is the solution concentration when the adsorption is at equilibrium $(\mathrm{mg} / \mathrm{L})$, $q$ is the adsorption capacity at the time of equilibrium $(\mathrm{mg} / \mathrm{g})$, and $\mathrm{H}$ is the adsorption efficiency $(\%)$.

\subsection{Equilibrium and Kinetic Modeling of the Phosphorus Decontamination Process onto $\mathrm{ZnO}$}

Equilibrium and kinetic modeling are essential in shedding light onto adsorption capacity. A number of different models were included: the pseudo first-order equation and second-order equation, as well as the Langmuir, Freundlich, Temkin, and Dubinin-Radushkevich equilibrium isotherm adsorption models. 


\section{Results and Discussion}

\subsection{Factors Affecting the Morphology and Surface Structure of ZnO Nanoparticles}

\subsubsection{SEM Image Analysis}

The SEM images of the as-synthesized $\mathrm{ZnO}$ are shown in Figure 1. Visually, the ZnO nanoparticle structures are interwoven with some nanorods. This may be due to the developing reaction of the $\mathrm{ZnO}$ nanoparticles to the nanorod structures. Figure 1 shows that the $\mathrm{ZnO}$ materials are of high porosity and had particle sizes widely distributed due to the integration of the $\mathrm{ZnO}$ nanoparticles and $\mathrm{ZnO}$ nanorods. This distribution can be confirmed by the laser diffraction method.

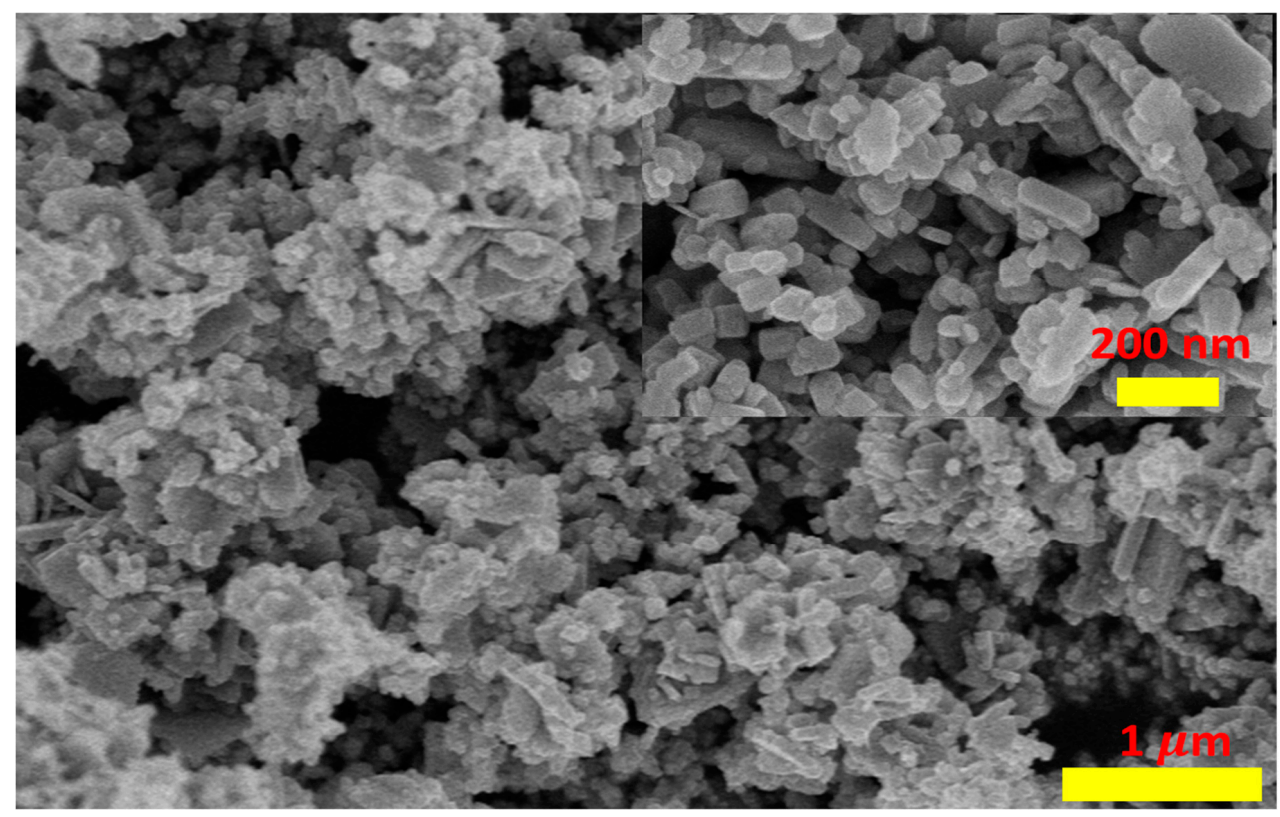

Figure 1. SEM image of the $\mathrm{ZnO}$ nanomaterials.

3.1.2. Determination of Surface Area by the BET Method

The $\mathrm{ZnO}$ samples were measured by $\mathrm{N}_{2}$ isotherm adsorption at $-196{ }^{\circ} \mathrm{C}$. The adsorption isotherm and $\mathrm{N}_{2}$ adsorption are shown in the Figure 2. The BET graph of the $\mathrm{ZnO}$ samples, obtained from the software, is also shown in Figure 3. The surface areas of the $\mathrm{ZnO}$ samples are $17.05 \mathrm{~m}^{2} / \mathrm{g}$.

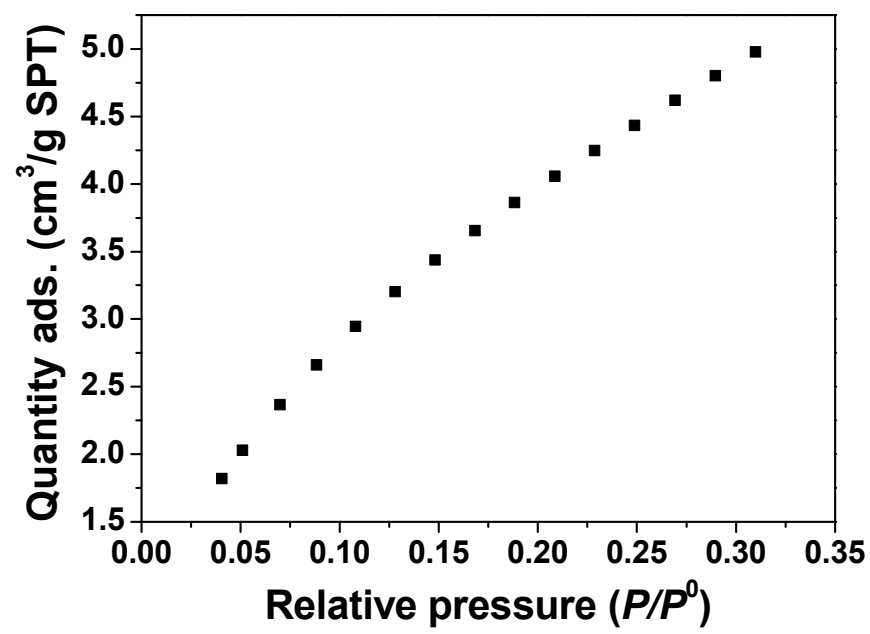

Figure 2. Adsorption isotherm- $\mathrm{N}_{2}$ adsorption of nano $\mathrm{ZnO}$, in the as-synthesis condition at a temperature of $180^{\circ} \mathrm{C}$. 


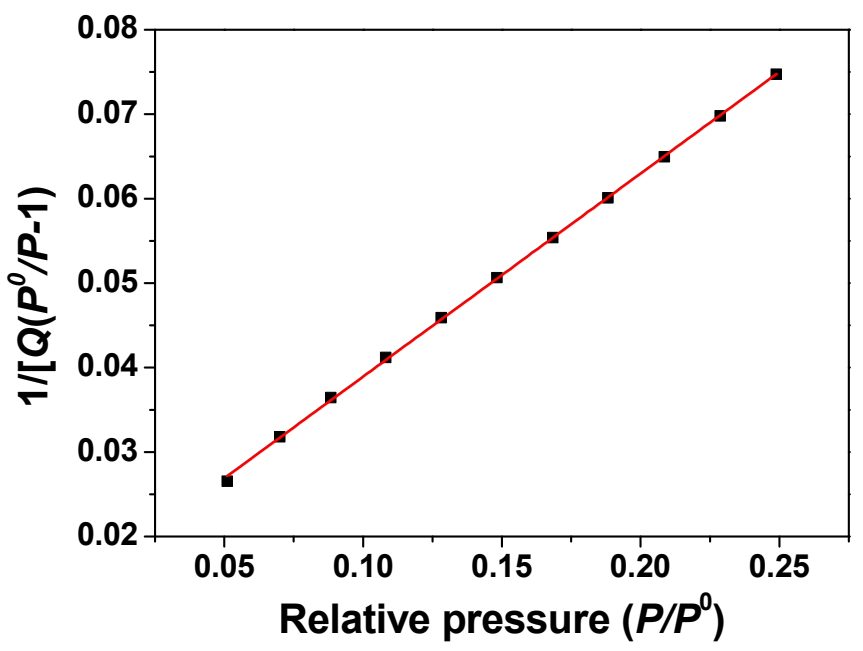

Figure 3. BET graph of the as-synthesized $\mathrm{ZnO}$ nanomaterials obtained at a synthesis temperature of $180^{\circ} \mathrm{C}$.

\subsection{Structure and Morphology}

\subsubsection{XRD Analysis}

The XRD patterns of the nano $\mathrm{ZnO}$ is shown in Figure 4, showing characteristic peaks at (100); (002); (101); (102); (110); (103); (112) and (201), which correspond to ZnO diffractions of its wurtzite structure.

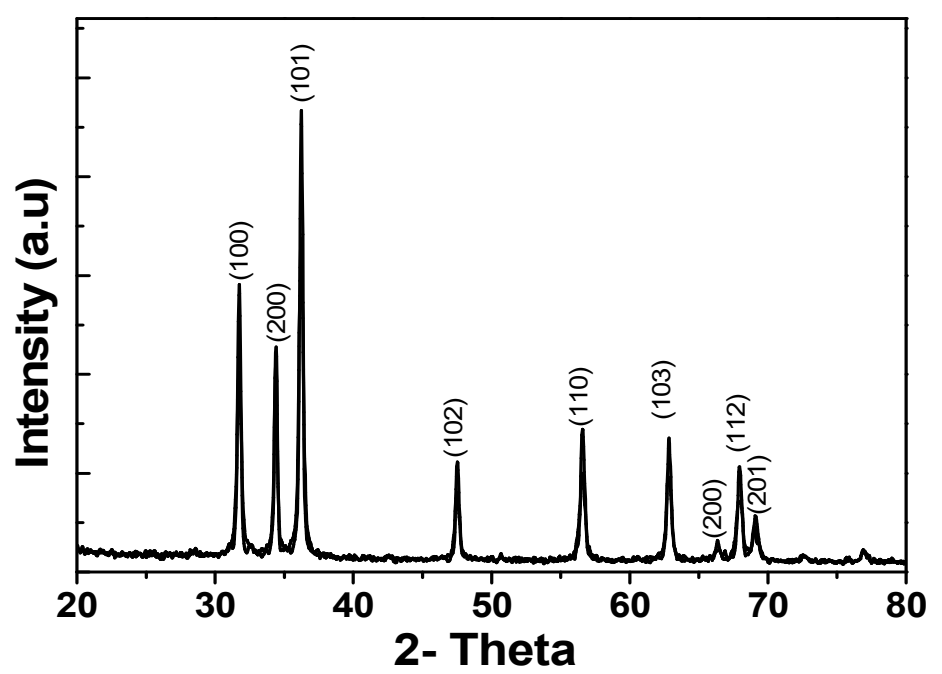

Figure 4. Results of the XRD patterns of $\mathrm{ZnO}$.

\subsubsection{EDS Analysis}

The chemical composition of the prepared $\mathrm{ZnO}$ samples was analyzed by the EDS method and the results are shown in Figure 5 and Table 1. From the EDS results, it is indicated that the surface composition of the $\mathrm{ZnO}$ is very pure, constituting about $99.99 \%$ of the $\mathrm{Zn}$ and $\mathrm{O}$, and that only a small quantity of carbon impurities is present in the composition, possibly due to the incomplete absorption of $\mathrm{CO}_{2}$ from the air or incomplete decomposition of the organic matter. 


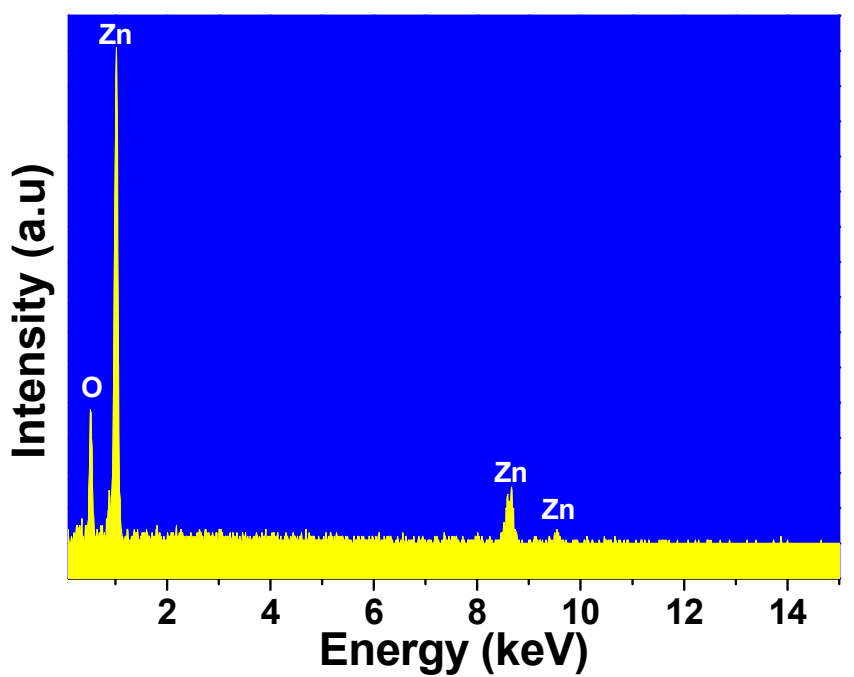

Figure 5. EDS pattern of the $\mathrm{ZnO}$ nanorods.

Table 1. Elemental analysis of the synthesized $\mathrm{ZnO}$ nanorods.

\begin{tabular}{ccc}
\hline Element & Theory & Result \\
\hline $\mathrm{Zn}$ & 80.34 & 80.32 \\
$\mathrm{O}$ & 19.66 & 19.67 \\
Total & 100.00 & 99.99 \\
\hline
\end{tabular}

\subsubsection{Particle-Size Distribution by Laser Diffraction}

The particle-size distribution in Figure 6, obtained by a laser diffraction analyzer, indicated that the majority of the $\mathrm{ZnO}$ particles, obtained at a synthesis temperature of $180{ }^{\circ} \mathrm{C}$, were sized around $0.814 \mu \mathrm{m}$. The range in which the $\mathrm{ZnO}$ particle size was measured was also low, suggesting that particles synthesized under this temperature condition was relatively stable in size. The first distribution peak is related to the $\mathrm{ZnO}$ nanoparticles. The second distribution peak is related to the nanorod.

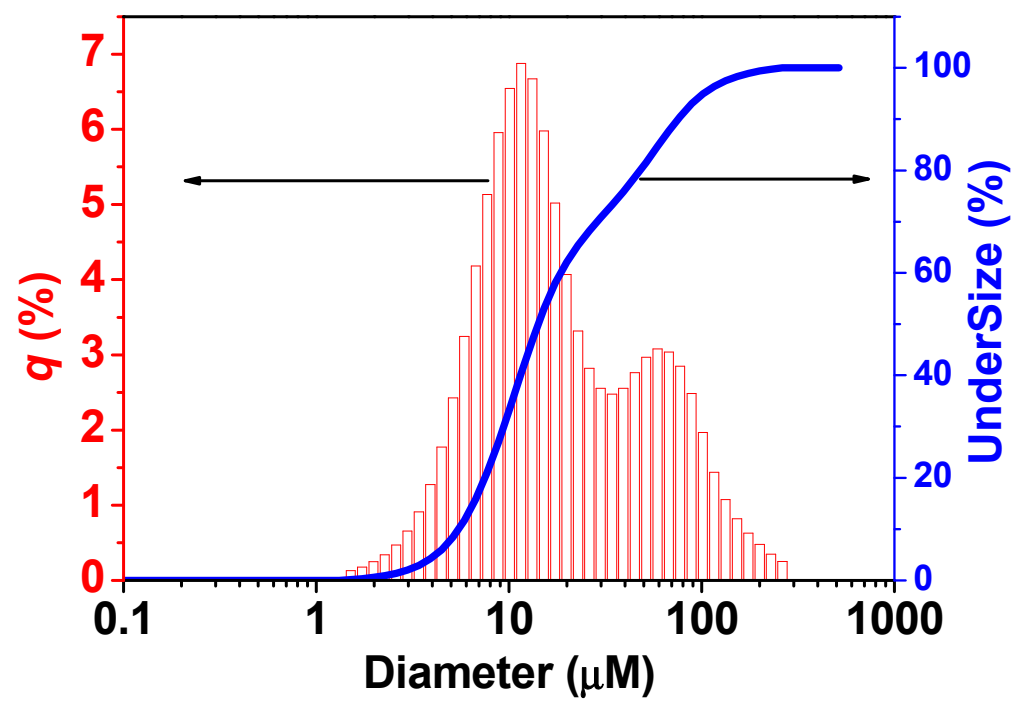

Figure 6. The synthesized $\mathrm{ZnO}$ nanoparticle-size distribution, as per the laser diffraction analyzer. 


\subsection{Determination of the Isoelectric Point of $\mathrm{ZnO}$}

To determine the isoelectric point of $\mathrm{ZnO}$, ten $0.1 \mathrm{M} \mathrm{NaCl}$ solutions were prepared with an initial $\mathrm{pH}\left(\mathrm{pH}_{\mathrm{i}}\right)$ ranging from 1 to 10 . In each flask, $0.025 \mathrm{~g}$ of prepared $\mathrm{ZnO}$ material was added, followed by $50 \mathrm{~mL}$ of the $\mathrm{NaCl}$ solution prepared above. The mixture was allowed to stand for $48 \mathrm{~h}$ before being filtered and re-measured for $\mathrm{pH}$. The results from Figure 7 suggests that the isoelectric point of $\mathrm{ZnO}$ is approximately 7.1. As a result, when the $\mathrm{pH}<\mathrm{pH}_{\mathrm{pzc}}$, the surface of the $\mathrm{ZnO}$ material is positively charged; otherwise, the surface of the $\mathrm{ZnO}$ material is negatively charged.

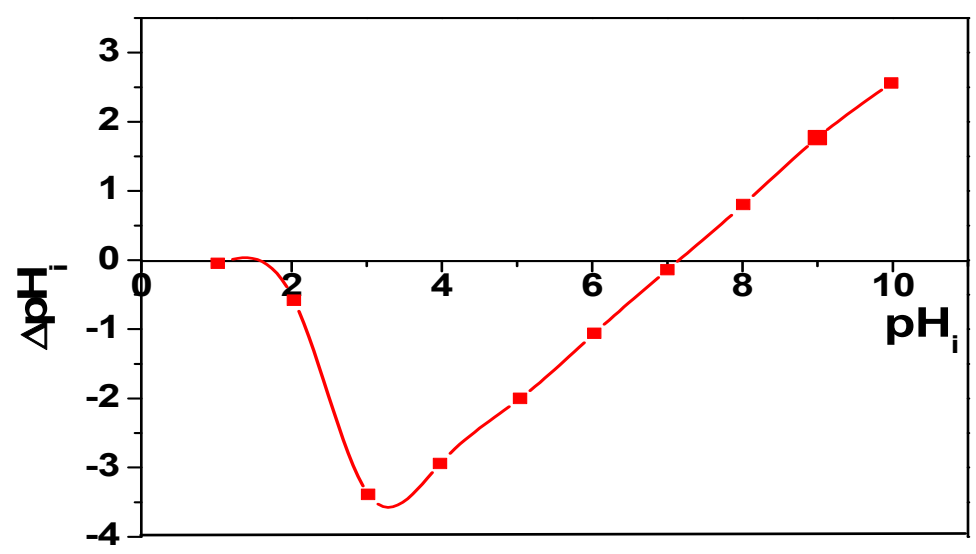

Figure 7. The graph for determination of the isoelectric point of $\mathrm{ZnO}$.

\subsection{Adsorption of Phosphate by $\mathrm{ZnO}$ Nanoparticles}

\subsubsection{Effect of $\mathrm{pH}$}

Controlling the $\mathrm{pH}$ of the media is critical for the efficiency of the adsorption process as it plays a key role in mediating the adsorbate behaviors and adsorption capacity of the adsorbent. As illustrated in Figure 8 , the adsorption efficiency was improved gradually and then eventually peaked when increasing the $\mathrm{pH}$ from 1 to 5 , with the maximum phosphorus adsorption efficiency reaching approximately $90 \%$. Afterwards, the efficiency dropped rapidly and at a $\mathrm{pH}$ of 10; the efficiency was reduced to $44.1 \%$. Therefore, the $\mathrm{pH}$ value at which the phosphorus removal was maximal was recorded within the range of 5-6. According to the thermodynamic calculations, three forms of phosphate, including $\mathrm{H}_{2} \mathrm{PO}_{4}^{-}$, $\mathrm{HPO}_{4}^{-2}$ and $\mathrm{PO}_{4}^{3-}$, with a pK of $2.15,7.20$ and 12.33 , respectively, existed in the aqueous solution and the ratio of the three forms is largely determined by $\mathrm{pH}$ of the solution. On the other hand, the point of zero charge $\left(\mathrm{pH}_{\mathrm{pzc}}\right)$, which could influence the surface adsorption capacity and active centers, is lower than the $\mathrm{pH}$ when the $\mathrm{pH}$ was in the range of 2 to 12 . As a result, the electrostatic repulsion and the competition between the $\mathrm{OH}^{-}$ions in occupying the active sites are also the driving force for the adsorption against phosphate. Conversely, in the case of $\mathrm{pH}<\mathrm{pH}_{\mathrm{pzc}}$, a positive charge of the sorbent surface might induce enhanced adsorption of the anions [19]. The reduced phosphorus adsorption at very high $\mathrm{pH}$ values could be explained by the competition of excessive $\mathrm{OH}^{-}$and phosphate anions, such as $\mathrm{H}_{2} \mathrm{PO}_{4}{ }^{-}, \mathrm{HPO}_{4}^{-2}$ and $\mathrm{PO}_{4}^{3-}$, onto the $\mathrm{ZnO}$ adsorption sites [22]. Another explanation for the $\mathrm{pH}$-dependent adsorption activity of $\mathrm{ZnO}$ is that protonation/deprotonation of the nano- $\mathrm{ZnO}$ surface is highly sensitive to the $\mathrm{pH}$ of the solution due to the amphoteric properties of the metal oxide surfaces. As a result, in the media that have a $\mathrm{pH}$ lower than the isoelectrical point of the $\mathrm{ZnO}$, the adsorption of the $\mathrm{H}^{+}$ions is promoted [23], thus leading to a positively charged $\mathrm{ZnO}$ surface and in turn facilitating the uptake of phosphate anions [24]. On the contrary, increasing the solution's pH further causes accumulation of the negative charges on both the nano- $\mathrm{ZnO}$ and the adsorbate, enhancing the electrical repulsive force between the two phases. Based on those observations, we proposed the adsorption mechanism of the phosphorus onto the $\mathrm{ZnO}$ particles as follows [25]:

$$
=\mathrm{Zn}-\mathrm{OH}+\mathrm{HPO}_{4}^{-2} \leftarrow \rightarrow=\mathrm{Zn}-\mathrm{PO}_{4}^{-2}+\mathrm{H}_{2} \mathrm{O}
$$




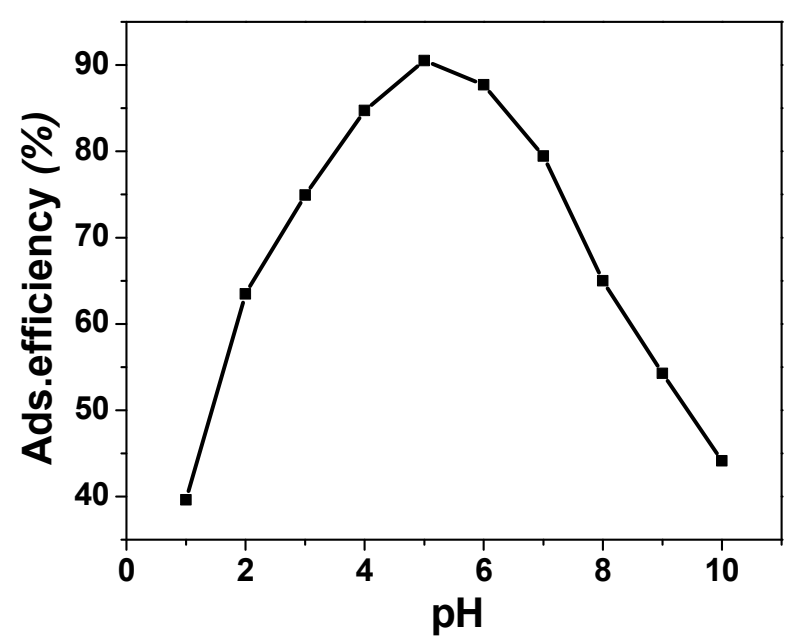

Figure 8. Effect of $\mathrm{pH}$ on the $\mathrm{PO}_{4}^{3-}$ adsorption efficiency.

It was shown that a higher solution $\mathrm{pH}$ is associated with degraded $\mathrm{P}$ adsorption. This suggests that the adsorption of phosphate anions could be hindered by a repulsive force caused by strong hydroxyl ions in the solution. Therefore, a $\mathrm{pH}=5$ was chosen for the next experiment.

\subsubsection{Effect of Contact Time}

Adsorption efficiencies with respect to contact duration are shown as in Figure 9. Generally, prolonging the stirring was positively correlated with the adsorption efficiency. In particular, a rapid adsorption improvement of $\mathrm{PO}_{4}^{3-}$ was observed in the first $150 \mathrm{~min}$. Afterwards, the adsorption efficiency increased marginally, insignificantly during the later period.

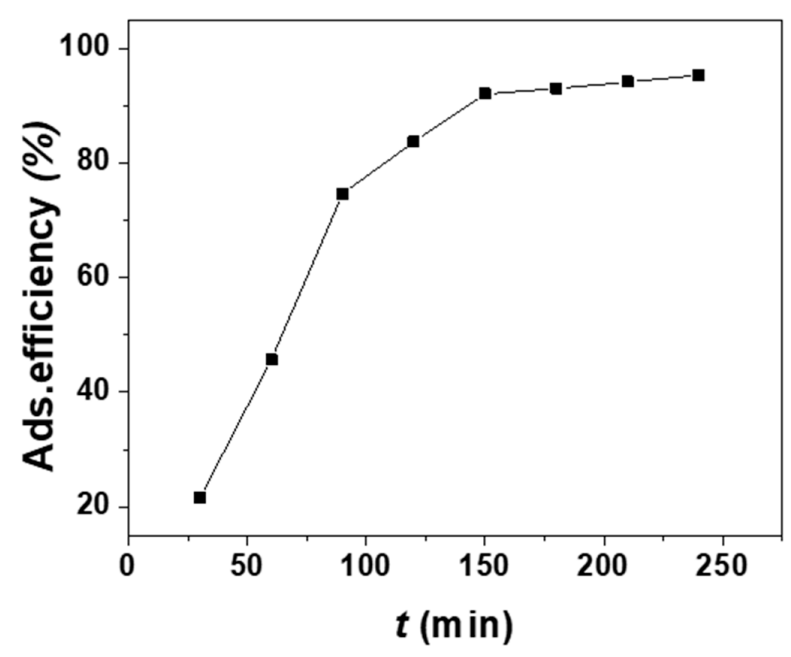

Figure 9. Effect of time on the $\mathrm{PO}_{4}^{3-}$ adsorption efficiency.

The accelerated $\mathrm{PO}_{4}^{3-}$ uptake in the beginning period is possibly due to the abundance of adsorption holes situated on the $\mathrm{ZnO}$ material surface. As those holes were occupied during the process, stagnant efficiency was observed in the later stage and then the adsorption reached the equilibrium state where no adsorption improvement took place with prolonged time. Therefore, the time needed for adsorption equilibrium was selected as $150 \mathrm{~min}$ for subsequent experiments.

\subsubsection{Effect of $\mathrm{ZnO}$ Dosage}

The dosage of the adsorbent is responsible for both adsorption efficiency and capacity. Figure 10 presents the phosphorus removal with respect to varying $\mathrm{ZnO}$ dosages. Other parameters included a 
contact time of $150 \mathrm{~min}$, initial solute concentration of $50 \mathrm{ppm}$ and solution $\mathrm{pH}$ of 5 . Increasing the dosage from 0.1 to $0.7 \mathrm{~g} / \mathrm{L}$ caused significant improvement in phosphorus adsorption, from $24.7 \%$ to $96.3 \%$, possibly due to enhanced availability of adsorption active sites that facilitates $\mathrm{P}$ ion binding [26]. On the other hand, further increasing the $\mathrm{ZnO}$ dose higher than $0.5 \mathrm{~g} / \mathrm{L}$ induced no clear P removal enhancement. This is possibly explained by saturated adsorption sites on the material surface caused by abundant active sites and the accumulation of material particles as effective surface area is lowered. Therefore, the optimal absorbent was selected as $0.5 \mathrm{~g} / \mathrm{L}$.

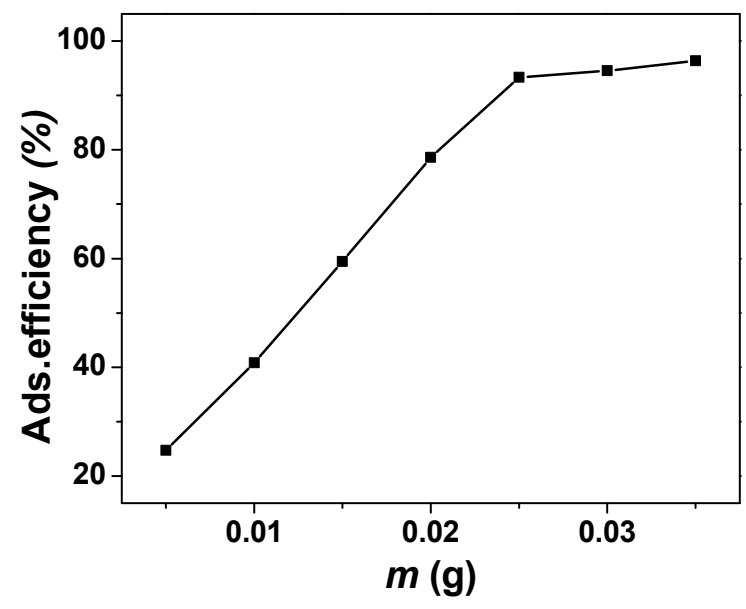

Figure 10. Effect of the adsorbent dose on the $\mathrm{PO}_{4}^{3-}$ adsorption efficiency.

\subsubsection{Effect of Temperature}

Figure 11 shows the effect of temperature on the adsorption efficiency of $\mathrm{PO}_{4}^{3-}$. It can be observed that the removal of $\mathrm{PO}_{4}^{3-}$ gradually increased when elevating the temperature from $298 \mathrm{~K}$ to $323 \mathrm{~K}$. This can be explained by the reduction in adsorption sites at higher temperatures. With the temperature increase from 298 to $323 \mathrm{~K}$, the adsorption efficiency declined slowly from 93 to 89\%. However, the amount of $\mathrm{PO}_{4}^{3-}$ adsorbed per unit volume of adsorbent will decrease as the temperature increases, suggesting that the adsorption of $\mathrm{PO}_{4}^{3-}$ by the $\mathrm{ZnO}$ nanomaterials is an exothermic process.

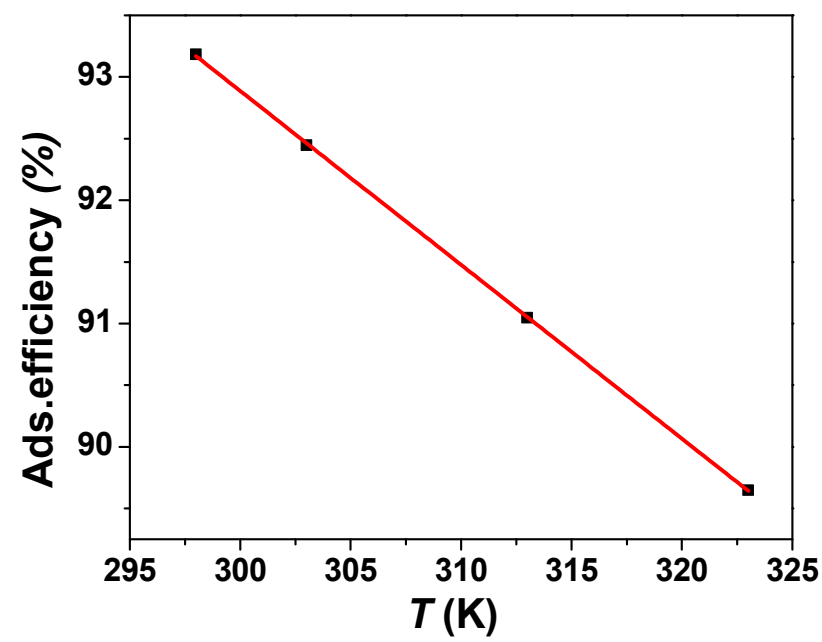

Figure 11. The effect of temperature on the efficiency of the $\mathrm{PO}_{4}^{3-}$ adsorption. 


\subsection{Adsorption Isotherm}

\subsubsection{Langmuir Isothermal Adsorption Model}

Adsorption isothermal analysis plays a very important role for the purpose of designing experiments and manufacturing adsorbents. Experimental data are analyzed with Langmuir isothermal models because they are classical and simple for describing the equilibrium between the adsorbed ions on adsorbents and ions in solution at a constant temperature.

The Langmuir equation can be written as follows:

$$
\frac{\mathrm{C}_{\mathrm{e}}}{q}=\frac{1}{q_{\max } \mathrm{K}}+\frac{\mathrm{C}_{\mathrm{e}}}{q_{\max }}
$$

where $q$ is specific adsorbance, which is the number of $\mathrm{mg}$ of adsorbent per $1 \mathrm{~g}$ of adsorbent at equilibrium $(\mathrm{mg} / \mathrm{g})$; $\mathrm{q}_{\max }$ : the maximum adsorption capacity $(\mathrm{mg} / \mathrm{g}) ; \mathrm{C}_{\mathrm{e}}$ : the concentration of the adsorbent in solution at equilibrium $(\mathrm{mg} / \mathrm{L})$; and $\mathrm{K}$ : Langmuir's constant.

When substituting $a$ and $b$ with

$$
\begin{gathered}
\mathrm{a}=\frac{1}{\mathrm{q}_{\max }} \\
\mathrm{b}=\frac{1}{\mathrm{~K} \cdot \mathrm{q}_{\max }}
\end{gathered}
$$

the above equation becomes $\mathrm{y}=\mathrm{ax}+\mathrm{b}$. From empirical calculations, it is possible to calculate the $\mathrm{K}$ constant and the maximum adsorption capacity $\left(q_{\max }\right)$. The graph of the Langmuir model is presented as in Figure 12. Inferring from the results, the maximum adsorption capacity $q_{\max }$ and the constant $\mathrm{K}$ was $769.23 \mathrm{mg} / \mathrm{g}$ and $0.12 \mathrm{~L} / \mathrm{mg}$, respectively. Although the $q_{\max }$ values might not represent an indication of adsorption capacity in the long term, it could serve as a measure for a comparative study of adsorbents. As indicated in Table 2, the prepared $\mathrm{ZnO}$ material showed an adsorption capacity of $769.23 \mathrm{mg} \mathrm{P} / \mathrm{g}$, which far exceeded that of previously reported adsorbents, implying that $\mathrm{ZnO}$ may be a promising candidate adsorbent for treatment of phosphate from aqueous environments.

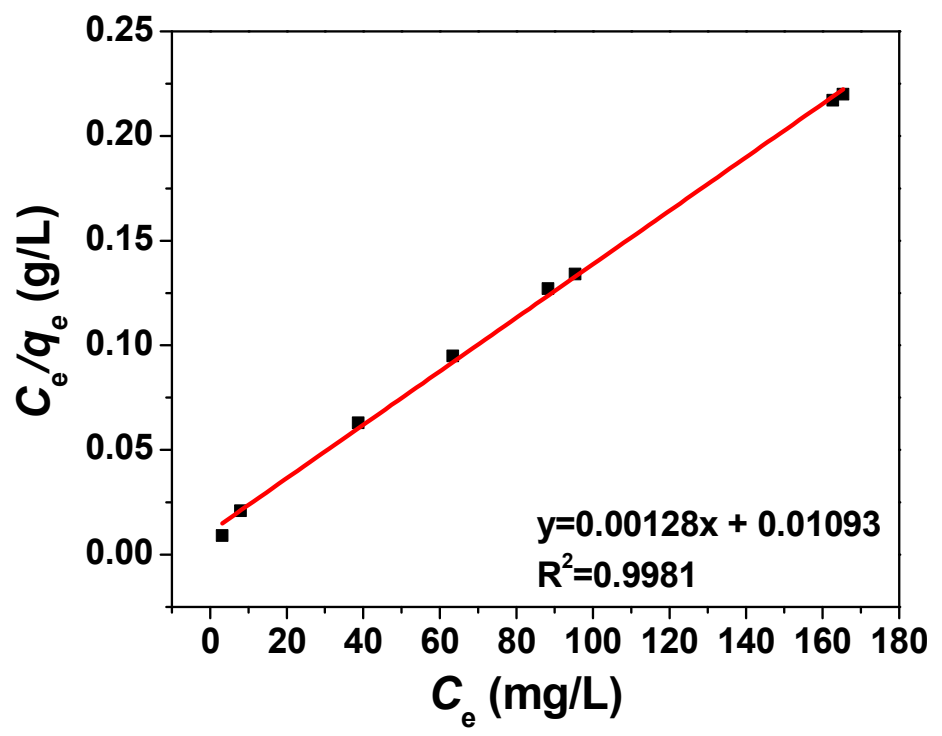

Figure 12. $C_{e} / q$ and $C_{e}$ correlations. 
Table 2. Maximum adsorption capacities of phosphorus onto various adsorbents.

\begin{tabular}{cccc}
\hline No. & Adsorbent & $\boldsymbol{q}_{\text {max }}(\mathbf{m g} / \mathbf{g})$ & Ref. \\
\hline 1 & $\mathrm{ZnO}$ & 168.4 & {$[27]$} \\
\hline 2 & $\mathrm{Zn}-\mathrm{Al}$ LDO $\left(573 \mathrm{~K}\right.$, Curea $\left.\frac{1}{4} 0.4 \mathrm{M}\right)$ & 232.0 & {$[28]$} \\
\hline 3 & $\mathrm{Zn}-\mathrm{Al} \mathrm{LDH}\left(\mathrm{Curea} \frac{1}{4} 0.4 \mathrm{M}\right)$ & 76.1 & {$[28]$} \\
\hline 4 & $\mathrm{ZnO}$ Nanorods & 89.0 & {$[25]$} \\
\hline 5 & $\mathrm{SnO}_{2}$ & 21.5 & {$[29]$} \\
\hline 6 & $\mathrm{WO}_{3}$ & 19.0 & {$[29]$} \\
\hline 7 & Fe(III)-Cu(II) binary oxides & 35.2 & {$[30]$} \\
\hline 8 & Silver nanoparticle-loaded activated carbon & 4.5 & {$[31]$} \\
\hline 9 & Magnetite-enriched particles (MEP) & 6.4 & {$[32]$} \\
\hline 10 & ZnO & 769.23 & Our work \\
\hline
\end{tabular}

The estimated results indicated that the Langmuir isotherm adsorption model described the adsorption process of $\mathrm{PO}_{4}^{3-}$ onto $\mathrm{ZnO}$ material, demonstrated by the high coefficient of determination (0.9983). Accordingly, the adsorption process is suggested to adhere to monolayer and chemical adsorption. Notably, those findings are larger than the previously published results [19-29].

In order to further justify the single layer adsorption of the $\mathrm{PO}_{4}^{3-}$ of $\mathrm{ZnO}$, we evaluated the suitability through the $\mathrm{R}_{\mathrm{L}}$ equilibrium parameter, which is calculated as

$$
\mathrm{R}_{\mathrm{L}}=\frac{1}{1+\mathrm{K}_{\mathrm{L}} \mathrm{C}_{\mathrm{O}}}
$$

where $\mathrm{C}_{\mathrm{o}}$ : initial concentration of the substance $(\mathrm{mg} / \mathrm{g})$; and $\mathrm{K}_{\mathrm{L}}$ : the Langmuir constant $(\mathrm{L} / \mathrm{mg})$.

The $\mathrm{R}_{\mathrm{L}}$ parameter calculated from Figure 13 ranged from 0.123 to 0.256 , which is lower than 1 . Thus, it can be confirmed that the Langmuir model is suitable for the absorption of $\mathrm{PO}_{4}^{3-}$ by $\mathrm{ZnO}$ nanomaterials.

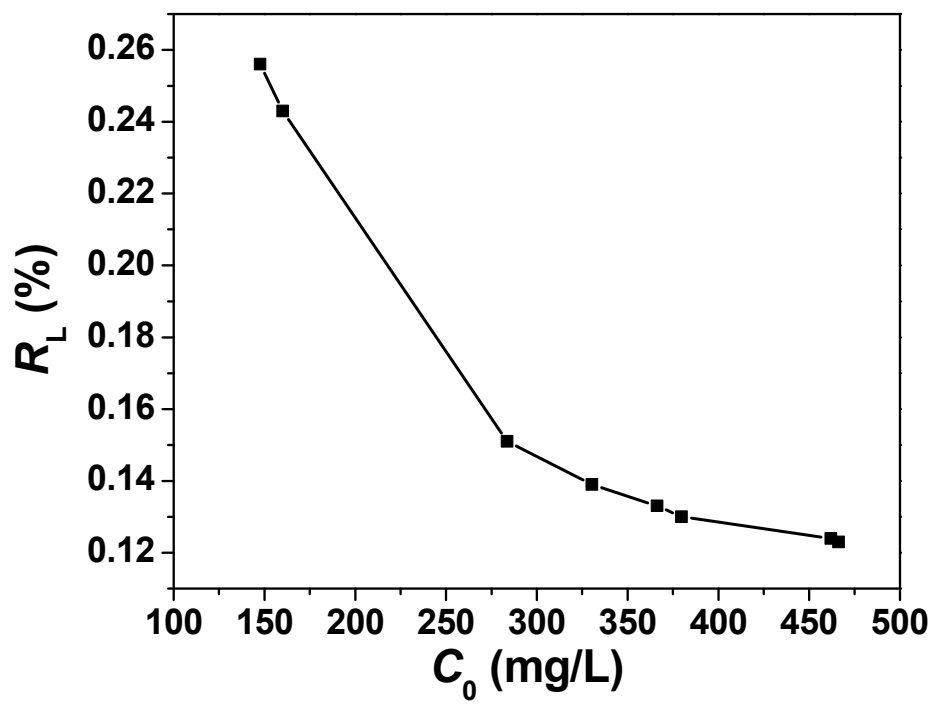

Figure 13. The dependence of $\mathrm{R}_{\mathrm{L}}$ on $\mathrm{C}_{\mathrm{o}}$ in the Langmuir model. 


\subsubsection{Freundlich Isothermal Adsorption Model}

The Freundlich isothermal adsorption model is an empirical equation based on adsorption on heterogeneous surfaces of materials. The linear equation is usually expressed as

$$
\log q_{\mathrm{e}}=\log \mathrm{k}+\frac{1}{n} \log \mathrm{C}_{\mathrm{e}}
$$

where $\mathrm{C}_{\mathrm{cb}}$ is the concentration at the time of equilibrium $(\mathrm{mg} / \mathrm{L})$; and $q_{\mathrm{e}}$ : the adsorption volume $(\mathrm{mg} / \mathrm{g})$. The constant $n$ is the exponent in the Freundlich equation, which characterizes the energy heterogeneity of the adsorbed surface; and k: the Freundlich constant, to show the relative adsorption capacity of the adsorbent materials.

The calculation results of the reactive red adsorption process of $\mathrm{PO}_{4}^{3-}$ on $\mathrm{ZnO}$ by the Freundlich adsorption isothermal model are displayed in Figure 14.

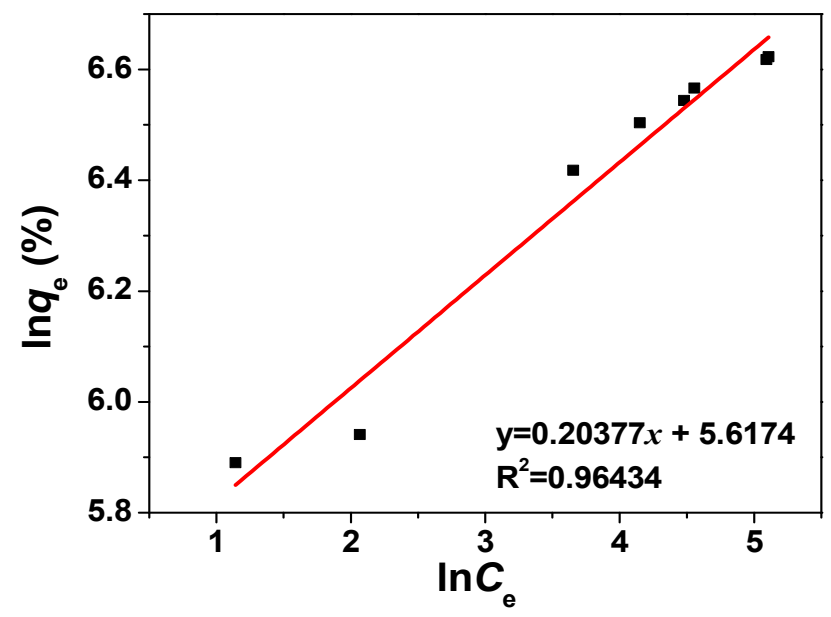

Figure 14. Dependence of $\log q$ on $\log \mathrm{C}_{\mathrm{e}}$ on $\mathrm{PO}_{4}^{3-}$.

Figure 14 expresses the absorption of $\mathrm{PO}_{4}^{3-}$ on $\mathrm{ZnO}$ materials according to the Freundlich isothermal adsorption model. The calculated $\mathrm{K}_{\mathrm{F}}$ was $275.145(\mathrm{mg} / \mathrm{g})(\mathrm{L} / \mathrm{mg})^{1 / \mathrm{n}}$ and the constant of $n$ was 4.907. The correlation coefficient, $R^{2}$, was 0.9697 . The $\mathrm{R}^{2}$ value of the Freundlich isotherm is lower than that of the Langmuir model. The value $n$ gives an indication of the favorability of the adsorption process. When the value of $n$ is less than 1 , the adsorption is said to be unfavorable, but if it is greater than 1 it is favorable [33]. The value of $n$ obtained in this study is greater than 1 , which indicates that the adsorption process is favorable.

\subsubsection{Dubinin-Radushkevich Isothermal Adsorption Model}

The Dubinin-Radushkevich (D-R) isotherm is more inclusive than the Langmuir isotherm for it does not assume a homogenous surface or constant sorption potential [34]. It is used for the estimation of the characteristic porosity of the biomass as well as the mean free energy of the adsorption. The linear form of the D-R model is presented as follows:

$$
\ln q=\ln q_{\max }-\beta . \varepsilon^{2}
$$

where:

$q$ : adsorption volume $(\mathrm{mg} / \mathrm{g})$;

$q_{\text {max }}$ : maximum adsorption volume $(\mathrm{mg} / \mathrm{g})$;

$\beta$ : constant of the adsorption energy $\left(\mathrm{mol}^{2} / \mathrm{J}^{2}\right)$; 
$\varepsilon:$ Polanyi, described as follows:

$$
\varepsilon=R \ln \left(1+\frac{1}{\mathrm{Ccb}}\right)
$$

where:

T: solution temperature $(\mathrm{K})$;

R: gas constant $\left(8.314 \times 10^{-3} \mathrm{~kJ} / \mathrm{mol} . \mathrm{K}\right)$.

The value of the average adsorption energy, $\mathrm{E}(\mathrm{kJ} / \mathrm{mol})$, can be calculated from $\mathrm{D}-\mathrm{R}$ according to parameter $\beta$ as follows:

$$
\mathrm{E}=\frac{1}{\sqrt{-2 \beta}}
$$

The value of the average adsorption energy indicates the nature of the adsorption process. When the $\mathrm{E}$ value is less than $8 \mathrm{~kJ} / \mathrm{mol}$, the adsorption process is physical adsorption and when the E value ranges from 8 to $16 \mathrm{~kJ} / \mathrm{mol}$, the adsorption is chemical.

The Dubinin-Radushkevich isothermal graph shown in Figure 15 reveals that phosphate adsorption does not follow the Dubinin-Radushkevich model, evidenced by the low $\mathrm{R}^{2}$.

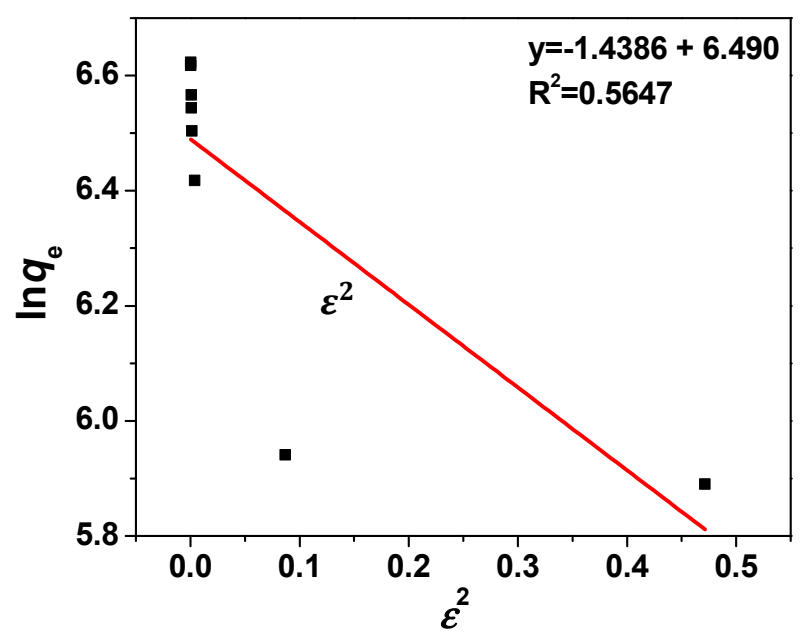

Figure 15. Dependence of lnq on $\varepsilon^{2}$ on $\mathrm{PO}_{4}^{3-}$ adsorption.

\subsubsection{Tempkin Isothermal Adsorption Model}

The isothermal model of Tempkin assumes that the adsorption heat of all the molecules on the surface of the material decreases linearly with the density of the coverage due to the interaction between the adsorbent and the substrate, and the adsorption is characterized by the uniform distribution of linked energy sources, up to a maximum number of associated energies. Temkin isotherms are represented by the following equation:

$$
q=\frac{\mathrm{RT}}{\mathrm{b}_{\mathrm{T}}} \ln \left(\mathrm{K}_{\mathrm{T}} \cdot \mathrm{C}_{\mathrm{cb}}\right)
$$

The equation can be expressed in linear form as

$$
q=\mathrm{B} \ln \mathrm{K}_{\mathrm{T}}+\mathrm{B} \ln \mathrm{C}_{\mathrm{cb}}
$$

where

$$
\mathrm{B}=\frac{\mathrm{RT}}{\mathrm{b}_{\mathrm{T}}}
$$


$\mathrm{T}$ : is the absolute temperature $(\mathrm{K})$;

R: gas constant (valued by $8.314 \times 10^{-3}(\mathrm{~kJ} / \mathrm{mol} . \mathrm{K})$;

$\mathrm{b}_{\mathrm{T}}$ : Tempkin constant $(\mathrm{kJ} / \mathrm{mol})$.

Determination of Temkin model parameters through plotting was described in Figure 16 and parameters of the models were summarized in Table 3.

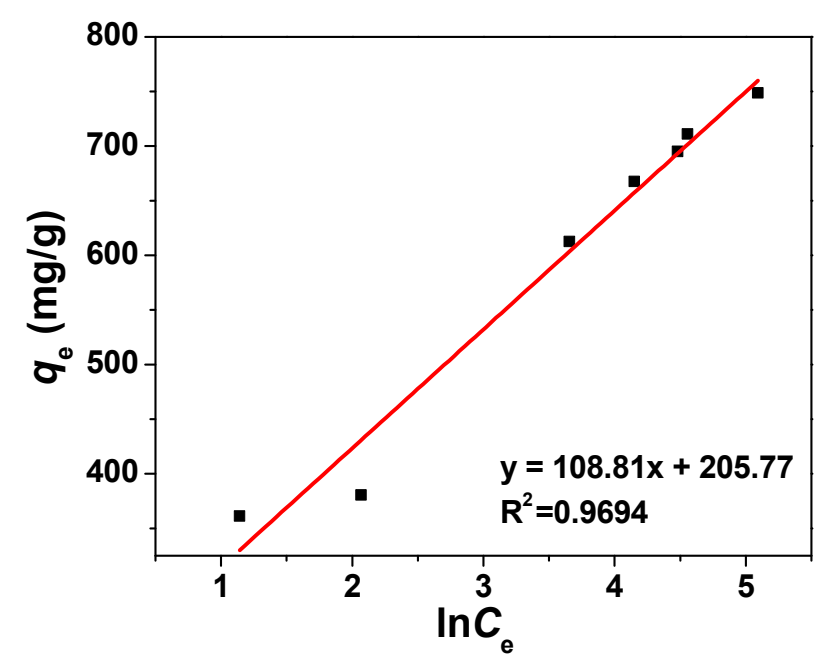

Figure 16. Dependence of $\mathrm{q}$ on $\ln \mathrm{C}_{\mathrm{cb}}$ on the adsorption of $\mathrm{PO}_{4}^{3-}$.

Table 3. Isothermal parameters: Langmuir, Freundlich, Tempkin and Dubinin-Radushkevich.

\begin{tabular}{ccc}
\hline Isothermal Line Model & \multicolumn{2}{c}{ Parameters } \\
\hline \multirow{2}{*}{ Langmuir } & $\mathrm{K}_{\mathrm{L}}(\mathrm{L} / \mathrm{mg})$ & 0.12 \\
\cline { 2 - 3 } & $q_{\mathrm{max}}(\mathrm{mg} / \mathrm{g})$ & 769.23 \\
\cline { 2 - 3 } Freundlich & $\mathrm{R}^{2}$ & 0.99 \\
\cline { 2 - 3 } & $\mathrm{K}_{\mathrm{F}}(\mathrm{mg} / \mathrm{g})(\mathrm{mg} / \mathrm{L})^{1 / \mathrm{n}}$ & 275.145 \\
\cline { 2 - 3 } Tempkin & $\mathrm{N}$ & 4.907 \\
\cline { 2 - 3 } & $\mathrm{R}^{2}$ & 0.97 \\
\cline { 2 - 3 } & $\mathrm{K}_{\mathrm{T}}(\mathrm{kJ} / \mathrm{mol})$ & 6.887 \\
\hline \multirow{2}{*}{ Dubinin-Radushkevich } & $\mathrm{R}^{2}$ & 0.023 \\
\cline { 2 - 3 } & $q_{\mathrm{max}}(\mathrm{mg} / \mathrm{g})$ & 0.9694 \\
\cline { 2 - 3 } & $\beta\left(\mathrm{mol}^{2} / \mathrm{J}^{2}\right)$ & 658.392 \\
\hline & $\mathrm{R}^{2}$ & -1.439 \\
\hline
\end{tabular}

From Table 3, the value of the Tempkin constant $b_{T}$ of 0.023 indicates the presence of a weak interaction between the adsorbents and supports the physical adsorption of phosphate by $\mathrm{ZnO}$ nanomaterials. The determination coefficient $\mathrm{R}^{2}$ of the Langmuir, Freundlich and Tempkin models are nearly equivalent $(0.99,0.97$ and 0.97$)$ whereas the Dubinin-Radushkevich model is 0.628. Thus, the phosphate adsorption of the $\mathrm{ZnO}$ nanomaterials do not seem to follow the Dubinin-Radushkevich model, but the isothermal adsorption models of Langmuir, Freundlich and Tempkin. The adsorption of phosphate onto the $\mathrm{ZnO}$ nanomaterials is a single layer under the condition of a heterogeneous surface and there is a weak interaction between the adsorbent and adsorbate. 


\subsection{Study on the Adsorption Kinetics of $\mathrm{PO}_{4}^{3-}$ on $\mathrm{ZnO}$ Nanomaterials}

The adsorption process of a solute could be conventionally described by the Lagergren rate equation, which could be presented in pseudo-first-order form as follows:

$$
\frac{\mathrm{d} q_{t}}{\mathrm{~d} t}=k_{1}\left(q_{e}-q_{t}\right)
$$

By taking the integral on both sides of the equation, with the boundary $t$ from 0 to $t$ and $q$ from 0 to $q_{t}$, the following equation is obtained:

$$
\mathrm{g}\left(q_{e}-q_{t}\right)=\lg q_{e}-\frac{k_{1}}{2.303} t
$$

where $q$ is the amount of adsorbed $\mathrm{PO}_{4}^{3-}(\mathrm{mg} / \mathrm{g})$. The subscript $t$ and $q$ denote the state at equilibrium and time $t$ ( $\mathrm{min})$, respectively. $k_{1}$ is the rate constant. Plotting $\ln \left(q_{e}-q_{t}\right)$ against $t$ gives the graph whose slope could be interpreted as the rate constant of the pseudo-first-order model.

The pseudo-second-order equation based on the adsorption equilibrium capacity can be expressed as

$$
\frac{\mathrm{d} q_{t}}{\mathrm{~d} t}=k_{2}\left(q_{e}-q_{t}\right)^{2}
$$

By taking a similar approach, one could derive the following integrated linear form of the pseudo-second-order as follows:

$$
\frac{t}{q_{t}}=\frac{1}{k_{2} \cdot q_{e}^{2}}+\frac{1}{q_{e}} t
$$

By linearly plotting time against $\log \left(q_{e}-q_{t}\right)$, the pseudo-first-order rate constant and sorption capacity could be calculated (Figure 17). On the other hand, the pseudo-second-order model could be plotted by considering $t / q_{t}$ as a function of $t$ (Figure 18). The model parameters are summarized as in Table 4. It was showed that the coefficient of determination of the pseudo-second-order is higher than that of the first-order model. In addition, the second-order model showed high agreement between the experimental $\left(q_{\mathrm{e}(\exp )}\right)$ and calculated $\left(q_{\mathrm{e}(\mathrm{cal})}\right)$ capacities, suggesting that the second-order model would be more appropriate to describe the sorption process.

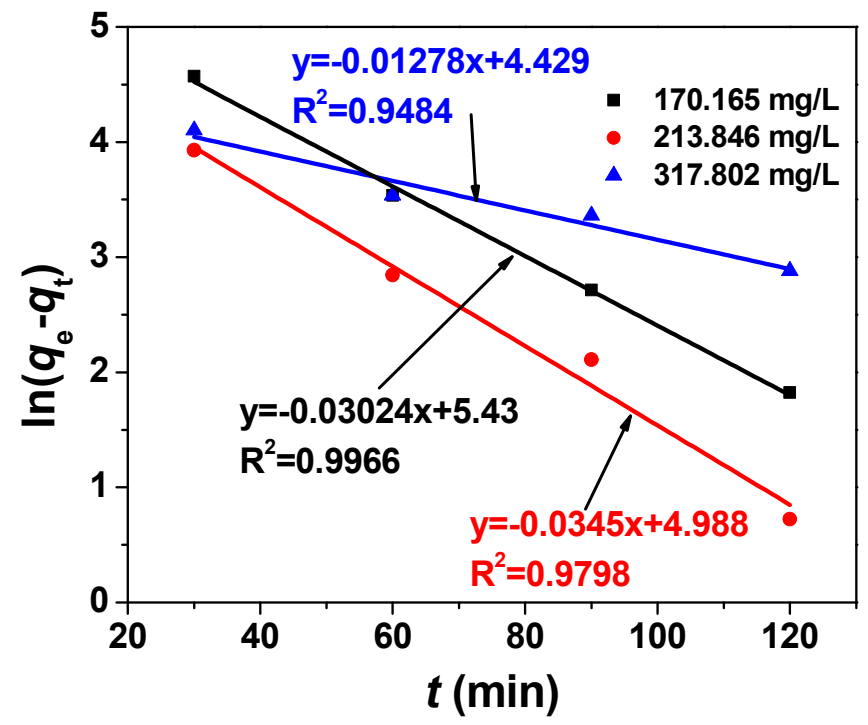

Figure 17. Pseudo-first-order non-linear method for adsorption of $\mathrm{PO}_{4}^{3-}$ onto $\mathrm{ZnO}$. 


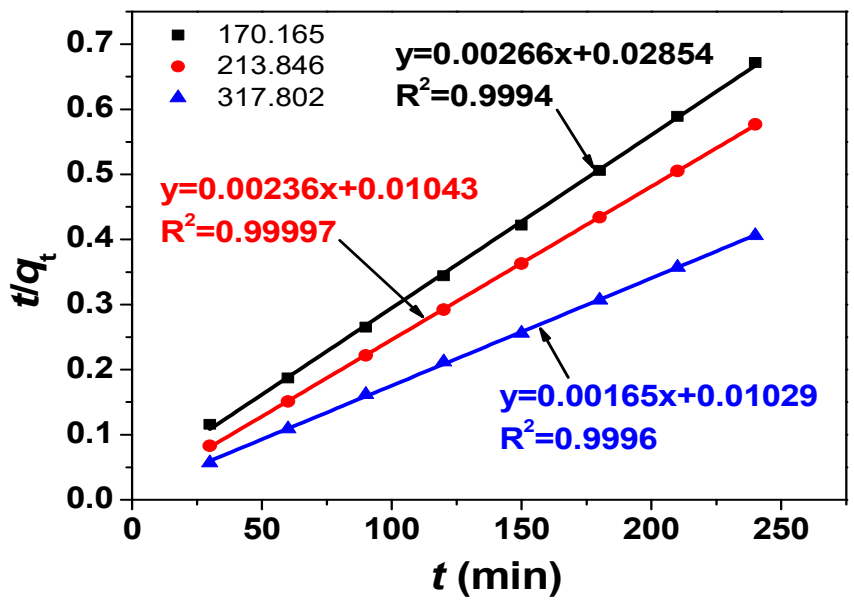

Figure 18. Pseudo-second-order non-linear method for adsorption of $\mathrm{PO}_{4}^{3-}$ onto $\mathrm{ZnO}$.

Table 4. Coefficients of the pseudo-first and second-order adsorption kinetic models and intraparticle diffusion model.

\begin{tabular}{|c|c|c|c|c|}
\hline Concentration (mg/L) & $q_{\text {e.exp }}(\mathrm{mg} / \mathrm{g})$ & $q_{\text {e.cal }}(\mathrm{mg} / \mathrm{g})$ & $\mathrm{k}_{1}\left(\mathrm{~min}^{-1}\right)$ & $\mathbf{R}^{2}$ \\
\hline \multicolumn{5}{|c|}{ Pseudo-first-order model } \\
\hline 51.765 & 29.984 & 20.289 & 0.0589 & 0.872 \\
\hline 71.350 & 39.436 & 30.033 & 0.0564 & 0.927 \\
\hline 103.546 & 53.768 & 42.897 & 0.0640 & 0.960 \\
\hline \multicolumn{5}{|c|}{ Pseudo-second-order model } \\
\hline Concentration (mg/L) & $q_{\text {e.exp }}(\mathrm{mg} / \mathrm{g})$ & $q_{\mathrm{e} . \mathrm{cal}}(\mathrm{mg} / \mathrm{g})$ & $\mathrm{k}_{2}$ (g/mg.min) & $R^{2}$ \\
\hline 51.765 & 30.073 & 30.959 & 0.015 & 0.999 \\
\hline 71.350 & 39.436 & 40.650 & 0.010 & 0.999 \\
\hline 103.546 & 53.590 & 54.645 & 0.010 & 0.999 \\
\hline
\end{tabular}

Given that the adsorption process obeys the second-order apparent kinetics model of Lagergren, the activation energy of the absorption can be determined by the formula

$$
\mathrm{k}_{2}=\mathrm{k}_{0} \exp \left(-\mathrm{E}_{\mathrm{a}} / \mathrm{RT}\right)
$$

where $\mathrm{k}_{2}$ is adsorption rate constant (g/mg.min); $\mathrm{k}_{0}$ is the initial rate constant; $\mathrm{E}_{\mathrm{a}}$ is the activation energy ( $\mathrm{kJ} / \mathrm{mol}) ; \mathrm{R}$ is the gas constant $(\mathrm{R}=8.314 \mathrm{~J} / \mathrm{mol} . \mathrm{K})$; and $\mathrm{T}$ is the absolute constant $(\mathrm{K})$. In the above equation, $\mathrm{k}_{2}$ can be replaced by $\mathrm{h}=\mathrm{k}_{2} \mathrm{q}_{\mathrm{e}}{ }^{2}$, reflecting the initial adsorption rate constant when $q_{\mathrm{t}} / t$ reaches zero, thus:

$\mathrm{k}_{2}=h \cdot \exp \left(-\mathrm{E}_{\mathrm{a}} / \mathrm{RT}\right)$

As a result,

$$
\mathrm{E}_{\mathrm{a}}=\mathrm{RT}\left(\operatorname{lnh}-\ln \mathrm{k}_{2}\right) .
$$

As previously reported [35], physisorption is due to weak van der Waal forces between the adsorbent and the adsorbate. The magnitude of the energy of physisorption is in the region of less than $20 \mathrm{~kJ} / \mathrm{mol}$. The same study also further stated that a covalent bond exists between the adsorbate and the adsorbent in chemisorption in which the substrate (adsorbent) is limited to monolayer coverage. The value of E, the mean free energy of the biosorption obtained in this study, as reflected in Table 5, was higher than $20 \mathrm{~kJ} / \mathrm{mol}$, and the Langmuir isotherm (monolayer coverage) best fitted the surface coverage in this study. 
Table 5. Activation energy of $\mathrm{PO}_{4}^{3-}$ adsorption on $\mathrm{ZnO}$ nanomaterials.

\begin{tabular}{|c|c|c|c|}
\hline Concentration $(\mathrm{mg} / \mathrm{L})$ & $\mathbf{h}$ & $\mathrm{k}_{2}$ (g/mg.min) & $\mathrm{E}_{\mathrm{a}}(\mathrm{kJ} / \mathrm{mol})$ \\
\hline 170.165 & 26.150 & $2.074 \times 10^{-4}$ & 23.394 \\
\hline 213.846 & 34.519 & $2.198 \times 10^{-4}$ & 23.938 \\
\hline 317.802 & 52.322 & $2.238 \times 10^{-4}$ & 24.923 \\
\hline
\end{tabular}

\subsection{Thermal Dynamic of Adbsorption of $\mathrm{PO}_{4}^{3-}$ onto $\mathrm{ZnO}$ Nanomaterials}

The free energy $\left(\Delta \mathrm{G}^{0}\right)$, enthalpy $\left(\Delta \mathrm{H}^{0}\right)$ and entropy variation $\left(\Delta \mathrm{S}^{0}\right)$ of the $\mathrm{PO}_{4}^{3-}$ adsorption process was calculated using the following equations:

$$
\begin{gathered}
K_{D}=\frac{q_{e}}{C_{\mathrm{cb}}} \\
\Delta \mathrm{G}^{0}=-\mathrm{RT} \ln K_{D} \\
\ln K_{D}=-\frac{\Delta \mathrm{G}^{0}}{\mathrm{RT}}=-\frac{\Delta \mathrm{H}^{0}}{\mathrm{RT}}+\frac{\Delta S^{0}}{R}
\end{gathered}
$$

where:

$\mathrm{KD}$ : equilibrium constant;

$q_{e}$ : adsorption volume at equilibrium $(\mathrm{mg} / \mathrm{g})$;

$C_{\mathrm{cb}}$ : concentration of the substrate at equilibrium $(\mathrm{mg} / \mathrm{L})$;

$R$ : gas constant;

T: temperature $(\mathrm{K})$.

According to the calculated parameters in Table 6, the nature of the $\mathrm{PO}_{4}^{3-}$ adsorption process onto the $\mathrm{ZnO}$ material was spontaneous, evidenced by negativity of the change of the free energy $\left(\Delta \mathrm{G}^{0}\right)$. The increase in $\Delta G^{0}$ could be attributed to the elevating temperature under which the adsorption of phosphorus took place. On the other hand, the negative value of $\Delta \mathrm{H}^{0}$ suggests the reaction was endothermic. The negative value of $\Delta S^{0}$ also indicated the stability of the solid-solution interface during the adsorption process [36].

Table 6. Values of the thermodynamic parameters $(\mathrm{kJ} / \mathrm{mol})$ for the adsorption of $\mathrm{PO}_{4}^{3-}$ onto $\mathrm{ZnO}$.

\begin{tabular}{cccc}
\hline $\mathbf{T}(\mathrm{K})$ & $\Delta \mathrm{G}^{\mathbf{0}}(\mathrm{kJ} / \mathrm{mol})$ & $\Delta \mathbf{H}^{\mathbf{0}}(\mathrm{kJ} / \mathrm{mol})$ & $\Delta \mathbf{S}^{\mathbf{0}}(\mathbf{k J} / \mathbf{m o l} . \mathrm{K})$ \\
\hline 298 & -8.73 & & \\
\hline 303 & -8.63 & -14.55 & -0.02 \\
\hline 313 & -8.44 & & \\
\hline 323 & -8.24 & & \\
\hline
\end{tabular}

\section{Conclusions}

A high adsorption efficiency of $\mathrm{ZnO}$ nanorods for phosphate ions was found by using the hydrothermal method. The $\mathrm{ZnO}$ showed a wurtzite structure with a specific surface area of $17.05 \mathrm{~m}^{2} / \mathrm{g}$ and its purity reached $99 \%$. The as-synthesized $\mathrm{ZnO}$ particles were used in the adsorption of phosphate in aqueous media. The $\mathrm{ZnO}$ materials were applied for adsorption of phosphate from water using batch experiments. The effects of $\mathrm{pH}(4-10)$, adsorption time (30-240 min), the amount of adsorbent $(0.1-0.7 \mathrm{~g} / \mathrm{L})$ and the initial concentration of phosphate $(147.637-466.209 \mathrm{mg} / \mathrm{L})$ on the adsorption efficiency were investigated. The optimum condition was found at $\mathrm{pH}=5$ and at an adsorption time of $150 \mathrm{~min}$. The adsorption fitted well with the Langmuir isotherm and the maximum adsorption capacity was calculated to be $769.23 \mathrm{mg} / \mathrm{g}$. These results show that $\mathrm{ZnO}$ nanomaterial is highly promising 
for adsorbing phosphate from water. The adsorption of phosphate onto $\mathrm{ZnO}$ nanomaterials follows the isothermal adsorption model of Langmuir, Tempkin and Freundlich with single-layer adsorption. There is a weak interaction between the adsorbent and adsorbate.

Author Contributions: Investigation, D.T.H., N.V.T., N.Q.D., C.M.N., N.T.C.Q. and L.V.T.; writing-original draft, D.T.H; writing-review and editing, L.V.T. All authors have read and agreed to the published version of the manuscript.

Funding: This study received no external funding.

Conflicts of Interest: The authors declare no conflict of interest.

\section{References}

1. Lee, S.-C.; Park, H.-H.; Kim, S.-H.; Koh, S.-H.; Han, S.-H.; Yoon, M.-Y. Ultrasensitive Fluorescence Detection of Alzheimer's Disease Based on Polyvalent Directed Peptide Polymer Coupled to a Nanoporous ZnO Nanoplatform. Anal. Chem. 2019, 91, 5573-5581. [CrossRef] [PubMed]

2. Zhou, T.; Hu, M.; He, J.; Xie, R.; An, C.; Li, C.; Luo, J. Enhanced catalytic performance of zinc oxide nanorods with crystal plane control. CrystEngComm 2019, 21, 5526-5532. [CrossRef]

3. Chen, W.; Han, J.; Yi, J. Nanostructured $\mathrm{SnO}_{2}$ - and $\mathrm{ZnO}$-Based Gas Sensors for Early Warning of Electrical Fires. Meet. Abstr. 2020, MA2020-01, 2176. [CrossRef]

4. Chao, J.; Chen, Y.; Xing, S.; Zhang, D.; Shen, W. Facile fabrication of ZnO/C nanoporous fibers and ZnO hollow spheres for high performance gas sensor. Sens. Actuators B Chem. 2019, 298, 126927. [CrossRef]

5. ZnO-based nanostructured electrodes for electrochemical sensors and biosensors in biomedical applications. Biosens. Bioelectron. 2019, 141, 111417. [CrossRef]

6. Kim, J.Y.; Vincent, P.; Jang, J.; Jang, M.S.; Choi, M.; Bae, J.-H.; Lee, C.; Kim, H. Versatile use of ZnO interlayer in hybrid solar cells for self-powered near infra-red photo-detecting application. J. Alloy. Compd. 2020, 813, 152202. [CrossRef]

7. Minami, T.; Nanto, H.; Takata, S. Highly Conductive and Transparent Aluminum Doped Zinc Oxide Thin Films Prepared by RF Magnetron Sputtering. Jpn. J. Appl. Phys. 1984, 23, L280-L282. [CrossRef]

8. Demirci, S.; Dikici, T.; Tünçay, M.M.; Kaya, N. A study of heating rate effect on the photocatalytic performances of $\mathrm{ZnO}$ powders prepared by sol-gel route: Their kinetic and thermodynamic studies. Appl. Surf. Sci. 2020, 507, 145083. [CrossRef]

9. Thambidurai, S.; Gowthaman, P.; Venkatachalam, M.; Suresh, S. Natural sunlight assisted photocatalytic degradation of methylene blue by spherical zinc oxide nanoparticles prepared by facile chemical co-precipitation method. Optik 2020, 207, 163865. [CrossRef]

10. Irshad, K.; Khan, M.T.; Murtaza, A. Synthesis and characterization of transition-metals-doped ZnO nanoparticles by sol-gel auto-combustion method. Phys. B: Condens. Matter 2018, 543, 1-6. [CrossRef]

11. Thakur, S.; Mandal, S.K. Effect of dilution in a hydrothermal process and post-synthetic annealing on the tailoring of hierarchical ZnO nanostructures. CrystEngComm 2020, 22, 3059-3069. [CrossRef]

12. Shokry Hassan, H.; Kashyout, A.B.; Morsi, I.; Nasser, A.A.A.; Raafat, A. Fabrication and characterization of gas sensor micro-arrays. Sens. Bio-Sens. Res. 2014, 1, 34-40. [CrossRef]

13. F Elkady, M.; Shokry Hassan, H. Equilibrium and dynamic profiles of azo dye sorption onto innovative nano-zinc oxide biocomposite. Curr. Nanosci. 2015, 11, 805-814. [CrossRef]

14. Rizzi, V.; D’Agostino, F.; Gubitosa, J.; Fini, P.; Petrella, A.; Agostiano, A.; Semeraro, P.; Cosma, P. An Alternative Use of Olive Pomace as a Wide-Ranging Bioremediation Strategy to Adsorb and Recover Disperse Orange and Disperse Red Industrial Dyes from Wastewater. Separations 2017, 4, 29. [CrossRef]

15. Li, N.; Tian, Y.; Zhao, J.; Zhan, W.; Du, J.; Kong, L.; Zhang, J.; Zuo, W. Ultrafast selective capture of phosphorus from sewage by 3D Fe $\mathrm{O}_{4} @ \mathrm{ZnO}$ via weak magnetic field enhanced adsorption. Chem. Eng. J. 2018, 341, 289-297. [CrossRef]

16. Nakarmi, A.; Bourdo, S.E.; Ruhl, L.; Kanel, S.; Nadagouda, M.; Kumar Alla, P.; Pavel, I.; Viswanathan, T. Benign zinc oxide betaine-modified biochar nanocomposites for phosphate removal from aqueous solutions. J. Environ. Manag. 2020, 272, 111048. [CrossRef]

17. Liu, Z.; Lu, Y.; Li, X.; Chen, H.; Hu, F. Adsorption of phosphate from wastewater by a ZnO-ZnAl hydrotalcite. Int. J. Environ. Anal. Chem. 2019, 99, 1415-1433. [CrossRef] 
18. Laliberté, G.; Lessard, P.; de la Noüe, J.; Sylvestre, S. Effect of phosphorus addition on nutrient removal from wastewater with the cyanobacterium Phormidium bohneri. Bioresour. Technol. 1997, 59, 227-233. [CrossRef]

19. Li, M.; Liu, J.; Xu, Y.; Qian, G. Phosphate adsorption on metal oxides and metal hydroxides: A comparative review. Environ. Rev. 2016, 24, 319-332. [CrossRef]

20. Lalley, J.; Han, C.; Li, X.; Dionysiou, D.D.; Nadagouda, M.N. Phosphate adsorption using modified iron oxide-based sorbents in lake water: Kinetics, equilibrium, and column tests. Chem. Eng. J. 2016, 284, 1386-1396. [CrossRef]

21. Almeelbi, T.; Bezbaruah, A. Aqueous phosphate removal using nanoscale zero-valent iron. In Proceedings of the Nanotechnology for Sustainable Development; Diallo, M.S., Fromer, N.A., Jhon, M.S., Eds.; Springer International Publishing: Cham, Switzerland, 2014; pp. 197-210.

22. Tu, Y.-J.; You, C.-F.; Chang, C.-K.; Chen, M.-H. Application of magnetic nano-particles for phosphorus removal/recovery in aqueous solution. J. Taiwan Inst. Chem. Eng. 2015, 46, 148-154. [CrossRef]

23. Akyol, A.; Yatmaz, H.C.; Bayramoglu, M. Photocatalytic decolorization of Remazol Red RR in aqueous ZnO suspensions. Appl. Catal. B Environ. 2004, 54, 19-24. [CrossRef]

24. Mohd Omar, F.; Abdul Aziz, H.; Stoll, S. Aggregation and disaggregation of ZnO nanoparticles: Influence of pH and adsorption of Suwannee River humic acid. Sci. Total Environ. 2014, 468-469, 195-201. [CrossRef]

25. Elkady, M.F.; Shokry Hassan, H.; Salama, E. Sorption Profile of Phosphorus Ions onto ZnO Nanorods Synthesized via Sonic Technique. J. Eng. 2016, 2016, 1-9. [CrossRef]

26. Elkady, M.F.; El-Sayed, E.M.; Farag, H.A.; Zaatout, A.A. Assessment of Novel Synthetized Nanozirconium Tungstovanadate as Cation Exchanger for Lead Ion Decontamination. J. Nanomater. 2014, 2014, 1-11. [CrossRef]

27. Luo, Z.; Zhu, S.; Liu, Z.; Liu, J.; Huo, M.; Yang, W. Study of phosphate removal from aqueous solution by zinc oxide. J. Water Health 2015, 13, 704-713. [CrossRef]

28. Zhou, J.; Yang, S.; Yu, J.; Shu, Z. Novel hollow microspheres of hierarchical zinc-aluminum layered double hydroxides and their enhanced adsorption capacity for phosphate in water. J. Hazard. Mater. 2011, 192, 1114-1121. [CrossRef]

29. Mahdavi, S.; Hassani, A.; Merrikhpour, H. Aqueous phosphorous adsorption onto $\mathrm{SnO}_{2}$ and $\mathrm{WO}_{3}$ nanoparticles in batch mode: Kinetic, isotherm and thermodynamic study. J. Exp. Nanosci. 2020, 15, 242-265. [CrossRef]

30. Li, G.; Gao, S.; Zhang, G.; Zhang, X. Enhanced adsorption of phosphate from aqueous solution by nanostructured iron(III)-copper(II) binary oxides. Chem. Eng. J. 2014, 235, 124-131. [CrossRef]

31. Trinh, V.T.; Nguyen, T.M.P.; Van, H.T.; Hoang, L.P.; Nguyen, T.V.; Ha, L.T.; Vu, X.H.; Pham, T.T.; Nguyen, T.N.; Quang, N.V.; et al. Phosphate Adsorption by Silver Nanoparticles-Loaded Activated Carbon derived from Tea Residue. Sci. Rep. 2020, 10, 1-13. [CrossRef]

32. Shahid, M.K.; Kim, Y.; Choi, Y.-G. Adsorption of phosphate on magnetite-enriched particles (MEP) separated from the mill scale. Front. Environ. Sci. Eng. 2019, 13, 71. [CrossRef]

33. Xiong, L.; Yang, Y.; Mai, J.; Sun, W.; Zhang, C.; Wei, D.; Chen, Q.; Ni, J. Adsorption behavior of methylene blue onto titanate nanotubes. Chem. Eng. J. 2010, 156, 313-320. [CrossRef]

34. Plaza Cazón, J.; Bernardelli, C.; Viera, M.; Donati, E.; Guibal, E. Zinc and cadmium biosorption by untreated and calcium-treated Macrocystis pyrifera in a batch system. Bioresour. Technol. 2012, 116, 195-203. [CrossRef] [PubMed]

35. Ajaelu, C.J.; Nwosu, V.; Ibironke, L.; Adeleye, A. Adsorptive removal of cationic dye from aqueous solution using chemically modified African Border Tree (Newbouldia laevis) bark. J. Appl. Sci. Environ. Manag. 2017, 21, 1323-1329. [CrossRef]

36. Zhu, N.; Yan, T.; Qiao, J.; Cao, H. Adsorption of arsenic, phosphorus and chromium by bismuth impregnated biochar: Adsorption mechanism and depleted adsorbent utilization. Chemosphere 2016, 164, 32-40. [CrossRef]

Publisher's Note: MDPI stays neutral with regard to jurisdictional claims in published maps and institutional affiliations. 